\title{
Histometric Study of Socket Healing after Tooth Extraction in Rats Treated with Diclofenac
}

\author{
Luciana Ibara YUGOSHI \\ Miguel Angel SALA \\ Luiz Guilherme BRENTEGANI \\ Teresa Lúcia LAMANO CARVALHO \\ Department of Morphology, Stomatology and Physiology, Faculty of Dentistry of Ribeirão Preto, \\ University of São Paulo, Ribeirão Preto, SP, Brazil
}

\begin{abstract}
The purpose of the present study was to investigate if diclofenac administration interferes with the time course of alveolar wound healing in rats. Forty-two Wistar rats were used, 21 rats received $10 \mathrm{mg} / \mathrm{kg} /$ day of diclofenac one day before and 4 days after extraction of the right maxillary incisors and 21 rats received saline. The animals were sacrificed 7,14 and 21 days after tooth extraction. Progressive new bone formation and a decrease in the volume fraction of blood clot and connective tissue from 1 to 3 weeks after tooth extraction was quantified using the histometric point-counting method. Diclofenac treatment caused a significant delay in new bone formation in association with an impairment of blood clot remission/organization.
\end{abstract}

Key Words: diclofenac, socket healing, tooth extraction.

\section{INTRODUCTION}

Diclofenac is a non-steroidal anti-inflammatory drug (NSAID) presenting significant analgesic and anti-inflammatory activities. Drugs of this type are commonly used in dental clinics to relieve pain after tooth extraction. There is evidence, however, that the NSAIDs may delay the repair of damaged tissues, such as the skin (1), uterine musculature (2), cartilage (3), fractured bone (4-6) and new bone formation after tooth extraction (7). Studies carried out on rodents have shown that NSAIDs may disturb not only bone healing but also normal bone growth. Several NSAIDs, including diclofenac, seem to cause a significant inhibition of femoral growth and a delay in parietal bone healing (8). Ibuprofen and indomethacin may also retard the healing of long bone fractures $(4,6,9)$. The same degree of inhibition of femoral healing was found regardless of whether indomethacin was given orally or locally applied to rats (5). The inhibitory action of indomethacin on parietal wound healing, however, seems to be weaker than that of the steroidal anti-inflammatory drug (SAID) dexamethasone (10). A marked impairment of alveolar wound healing following prednisolone (a steroidal antiinflammatory drug) treatment was observed in rats (11).

The aim of the present study was to evaluate the effect of diclofenac sodium on the alveolar healing following tooth extraction in rats by morphometric analysis.

\section{MATERIAL AND METHODS}

Male Wistar rats, about 70 days old, (200-210 g body weight) were anesthetized with an intraperitoneal injection of 2,2,2-tribromoethanol ( $25 \mathrm{mg} / 100 \mathrm{~g}$ body weight; Sigma-Aldrich, St. Louis, MO, USA). The maxillary right incisors were extracted with a forceps after disconnection of the surrounding gingiva and luxation with an enamel hatchet with a cutting edge. Immediately after surgery, the gingival tissues were sutured with monofilament (Johnson \& Johnson, New Brunswick, NJ, USA) and a single intramuscular dose of antibiotic $(0.2 \mathrm{ml} / \mathrm{rat}$; Pentabiótico Veterinário, Wyeth, São Bernardo do Campo, SP, Brazil) was given.

The animals of the treated groups $(n=21)$ received intraperitoneal injections of diclofenac $(10 \mathrm{mg} /$ 
kg/day; Novartis, São Paulo, SP, Brazil) from the day before surgery until 4 days after tooth extraction. Control rats $(n=21)$ received the same volume of saline intraperitoneally.

The animals were sacrificed by decapitation 1, 2 and 3 weeks postoperatively ( $n=7$ per group), their mandibles were removed, and heads were immersed in $10 \%$ formalin for 48 hours. After fixation, the maxilla was dissected and divided along the median sagittal plane. The right halves were cut tangentially to the distal surface of the molars, decalcified, and processed for paraffin embedding. Longitudinal semiserial $6-\mu \mathrm{m}$ thick sections, cut at intervals of $60-\mu \mathrm{m}$, were stained with hematoxylin and eosin.

\section{Histometric Analysis}

A light camera (Zeiss, Jena) was used to measure the volume fraction of the alveolar components by a differential point-counting method, as previously described (12). Microscopic images of the alveolus (final magnification 420X) were superimposed on sheets of paper with a grid containing 100 equidistant points. Four thousand points lying on connective tissue and trabecular bone were counted in the apical, middle and cervical thirds of each alveolus. Data were analyzed statistically by the non-parametric Mann-Whitney test (GMC Basic Software, version 7.5, FORP-USP, Ribeirão Preto, SP, Brazil).

\section{RESULTS AND DISCUSSION}

The different phases of alveolar wound healing, observed by histological examination from 1 to 3 weeks after dental extraction, closely resembled histologic data regarding white rats (12-14). At the end of the first week, the alveolus of control animals was filled with immature connective tissue rich in fibroblasts and neoformed capillaries (granulation tissue). Newly formed trabecular bone was observed mainly on the internal surfaces of the alveolar socket and remnants of the blood clot were observed mainly in the apical third. Compared to controls, treated rats seemed to present a larger amount of blood clot in association with smaller amounts of connective tissue and bone. From the second week on, control and treated rats had an increase in
Table 1. Volume fraction (\%) of blood clot in the apical, middle and cervical alveolar thirds of control and diclofenac treated rats from 1 to 3 weeks following tooth extraction.

\begin{tabular}{|c|c|c|c|c|c|c|}
\hline & \multicolumn{6}{|c|}{ Blood Clot } \\
\hline & \multicolumn{2}{|c|}{1 week } & \multicolumn{2}{|c|}{2 weeks } & \multicolumn{2}{|c|}{3 weeks } \\
\hline & Control & Treated & Control & Treated & Control & Treated \\
\hline \multicolumn{7}{|l|}{ apical } \\
\hline Median & 20.2 & $32.0^{*}$ & 10.0 & $24.4^{*}$ & 9.9 & 21.8 \\
\hline $25 \%$ & 18.9 & 26.8 & 5.6 & 22.2 & 3.4 & 0.6 \\
\hline $75 \%$ & 22.0 & 38.4 & 15.2 & 33.4 & 10.3 & 28.1 \\
\hline \multicolumn{7}{|l|}{ Giddle } \\
\hline Median & 2.0 & $10.0^{*}$ & 4.0 & $13.2^{*}$ & 1.0 & $6.4^{*}$ \\
\hline $25 \%$ & 1.3 & 8.7 & 3.5 & 11.1 & 0.7 & 1.8 \\
\hline $75 \%$ & 9.0 & 20.5 & 4.9 & 25.9 & 1.5 & 7.9 \\
\hline \multicolumn{7}{|l|}{ ervical } \\
\hline Median & 3.0 & 14.7 & 1.7 & $8.8^{*}$ & 1.0 & 0.7 \\
\hline $25 \%$ & 2.2 & 0.7 & 1.0 & 3.4 & 0.0 & 0.0 \\
\hline $75 \%$ & 8.5 & 20.1 & 3.5 & 16.0 & 1.9 & 4.5 \\
\hline
\end{tabular}

Data are reported as median, $25 \%$ and $75 \%$ range. *Statistically different from the respective control $(\alpha=0.05)$.

the relative volume of trabecular bone in parallel to a decrease in the amount of blood clot and connective tissue. In treated rats, however, the volume fraction of blood clot and connective tissue was greater, causing a smaller quantity of trabecular bone (Figure 1) .

Histometric data provided quantitative results confirming the histologic findings (Tables 1-3). Diclofenac treatment caused a significant decrease in bone volume fraction which was more pronounced from the second week on. The relative amount of connective tissue was smaller in the alveolus of treated rats by the end of the first week (compatible with a delay in blood clot remission and organization) but was greater by the end of the third week (as a consequence of a delay in the osteogenic process). The volume fraction of blood clot was always greater in the alveolar socket of treated animals.

Blood clot formation is a fundamental step for the subsequent phases of tissue repair. The fibrin network allows invasion by fibroblasts, endothelial cells and macrophages, which are present in the remaining periodontal ligament. New fibroblasts, produced by differentiation of adventitial cells and mitosis of preexisting fibroblasts under the influence of growth factor released by platelets, synthesize a delicate collagen 
Table 2. Volume fraction (\%) of connective tissue in the apical, middle and cervical alveolar thirds of control and diclofenac treated rats from 1 to 3 weeks following tooth extraction.

\begin{tabular}{|c|c|c|c|c|c|c|}
\hline & \multicolumn{6}{|c|}{ Connective Tissue } \\
\hline & \multicolumn{2}{|c|}{1 week } & \multicolumn{2}{|c|}{2 weeks } & \multicolumn{2}{|c|}{3 weeks } \\
\hline & Control & Treated & Control & Treated & Control & Treated \\
\hline \multicolumn{7}{|l|}{ Apical } \\
\hline Median & 68.4 & $61.2 *$ & 65.8 & 64.7 & 59.6 & 56.2 \\
\hline $25 \%$ & 67.0 & 55.4 & 63.4 & 59.8 & 54.4 & 48.5 \\
\hline $75 \%$ & 72.7 & 64.2 & 69.6 & 69.6 & 61.9 & 76.3 \\
\hline \multicolumn{7}{|l|}{ Middle } \\
\hline Median & 77.6 & 73.6 & 59.2 & 58.7 & 56.4 & $61.8 *$ \\
\hline $25 \%$ & 73.1 & 68.4 & 56.6 & 51.1 & 55.9 & 59.2 \\
\hline $75 \%$ & 78.7 & 78.4 & 66.5 & 62.8 & 61.0 & 68.5 \\
\hline \multicolumn{7}{|l|}{ Cervical } \\
\hline Median & 84.0 & 82.0 & 63.5 & 64.9 & 60.1 & $77.9 *$ \\
\hline $25 \%$ & 81.6 & 72.6 & 60.2 & 57.2 & 50.6 & 66.6 \\
\hline $75 \%$ & 86.6 & 88.0 & 70.2 & 70.6 & 63.5 & 78.9 \\
\hline
\end{tabular}

Data are reported as median, $25 \%$ and $75 \%$ range. *Statistically different from the respective control $(\alpha=0.05)$.

Table 3. Volume fraction (\%) of bone trabeculae in the apical, middle and cervical alveolar thirds of control and diclofenac treated rats from 1 to 3 weeks following tooth extraction.

\begin{tabular}{|c|c|c|c|c|c|c|}
\hline & \multicolumn{6}{|c|}{ Trabecular Bone } \\
\hline & \multicolumn{2}{|c|}{1 week } & \multicolumn{2}{|c|}{2 weeks } & \multicolumn{2}{|c|}{3 weeks } \\
\hline & Control & Treated & Control & Treated & Control & Treated \\
\hline \multicolumn{7}{|l|}{ Apical } \\
\hline Median & 9.5 & 6.9 & 24.2 & $6.8^{*}$ & 30.2 & $22.0 *$ \\
\hline $25 \%$ & 8.2 & 6.6 & 17.9 & 6.0 & 28.9 & 18.6 \\
\hline $75 \%$ & 11.4 & 8.2 & 27.2 & 9.3 & 39.0 & 25.2 \\
\hline \multicolumn{7}{|l|}{ Middle } \\
\hline Median & 17.4 & $12.8^{*}$ & 36.2 & $23.5^{*}$ & 42.7 & $31.5 *$ \\
\hline $25 \%$ & 16.9 & 7.6 & 30.4 & 23.3 & 37.8 & 26.1 \\
\hline $75 \%$ & 22.0 & 15.0 & 37.9 & 27.2 & 43.0 & 35.0 \\
\hline \multicolumn{7}{|l|}{ Cervical } \\
\hline Median & 12.4 & 6.7 & 32.4 & 26.2 & 37.0 & $22.1 *$ \\
\hline $25 \%$ & 8.0 & 5.2 & 28.4 & 23.3 & 36.3 & 19.3 \\
\hline $75 \%$ & 13.6 & 9.8 & 37.2 & 30.5 & 48.0 & 28.6 \\
\hline
\end{tabular}

Data are reported as median, $25 \%$ and $75 \%$ range. $*$ Statistically different from the respective control $(\alpha=0.05)$. matrix which, in addition to newly formed capillaries, is characteristic of granulation tissue. The macrophages are essential for clot remission as this tissue undergoes maturation with the progressive apposition of collagen and production of bone matrix by osteoblasts $(15,16)$.

Despite the unequivocal evidence that the NSAIDs may delay the recovery of damaged tissues, the precise mechanism of this deleterious action is not fully understood and it is generally accepted that different NSAIDs may act differently (6). The inhibitory effect of indomethacin on tooth extraction wound healing in rats has been attributed to a probable interference with osteoblast and osteoclast function (7). Considering that the presence of optimal inflammation is essential for proper wound healing, it has been proposed that the NSAIDs ibuprofen and diclofenac hinder rat skin repair by virtue of depressing the inflammatory process (17). Lindholm and Tornkvist (4) suggested that the inhibitory effect of ibuprofen on new bone formation following tibial fracture in rats may be explained as a direct effect on boneforming cells on endosteal surfaces. Comparing the depressing effects of dexamethasone (representative of SAID) and indomethacin (representative of NSAID) on rat parietal bone healing, further evidence has been provided that the former has a greater deleterious effect, probably due to interference with calcium metabolism (increased bone resorption caused by reduction of calcium absorption) which results in impairment of acid mucopolysaccharide removal and delay of trabecular bone mineralization (10). The weaker inhibitory effect of indomethacin, on the other hand, seems to occur at an earlier stage than that of bone mineralization. Altman et al. (6) reported that both ibuprofen and indomethacin retarded femoral fracture healing in rats, as determined by mechanical testing and histologic analysis, and discussed their results on the basis of the inhibitory effect of NSAIDs on prostaglandin E-2 and local growth factor production.

By the end of week 3, alveolar bone healing in diclofenac-treated rats was hindered not only by larger remnants of blood clot but 

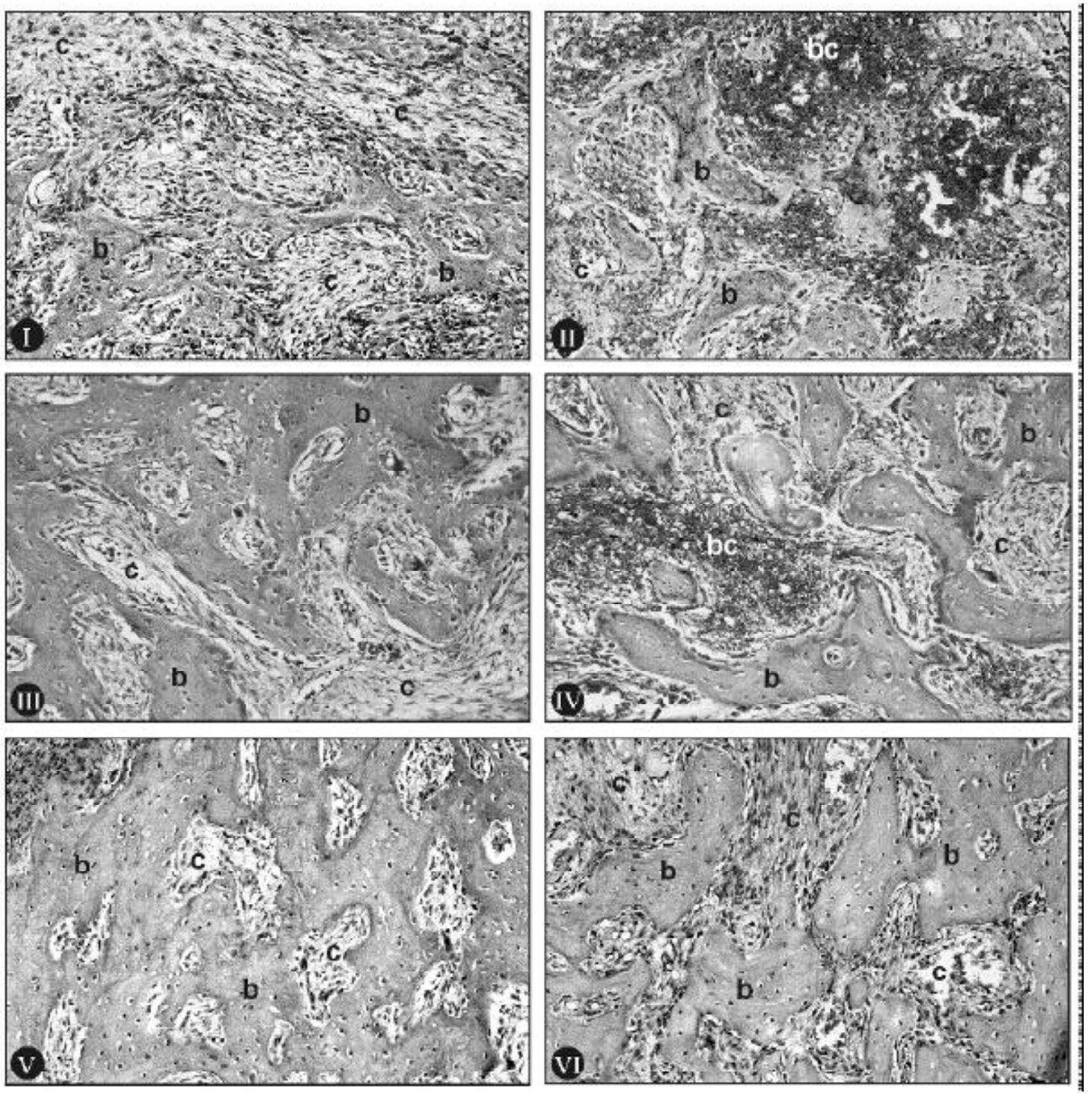

Figure 1. Alveolar wound healing 7 days (I and II), 14 days (III and IV) and 21 days (V and VI) after tooth extraction. I, III and V controls; II, IV and VI - treated with diclofenac. $\mathrm{c}=$ connective tissue, $\mathrm{b}=$ bone, $\mathrm{bc}=$ blood clot. H\&E; original magnification $=56 \mathrm{X}$.

also by the persistence of a greater volume fraction of connective tissue. The latter phenomenon may be caused by an impaired collagen synthesis/degradation ratio, as proposed by Abdalla et al. (2) to explain delayed repair in experimentally damaged myometrium in rats. The authors reported data showing that indomethacin may inhibit collagenase output by macrophages in vitro, an effect which is reversed by the addition of E2-prostaglandin to the culture.

Even though the animal used in this study was the rat, the results revealed significant information associated to a therapy widely used in clinical dentistry.

\section{RESUMO}

Yugoshi LI, Sala MA, Brentegani LG, Lamano Carvalho TL. Estudo histométrico do reparo alveolar após extração dental em ratos tratados com diclofenaco. Braz Dent J 2002;13(2):92-96.

O objetivo do presente trabalho foi investigar se a administração de diclofenaco interfere no processo de reparo alveolar em ratos. 
foram utilizados 42 ratos Wistar, dos quais 21 receberam 10mg/ $\mathrm{kg} /$ dia de diclofenaco e o restante solução salina. Os animais foram submetidos a extração dos incisivos superiores direito, e sacrificados 7, 14 e 21 dias após a avulsão dental. A formação progressiva de osso e a redução do volume de coágulo sangüíneo e tecido conjuntivo no período de 1 a 3 semanas após a extração dental foram quantificadas através do método histométrico de contagem de pontos. $\mathrm{O}$ tratamento com o diclofenaco causou significante atraso na neo-formação óssea, associado a um atraso na organização e remissão do coágulo sangüíneo.

Unitermos: diclofenaco, alvéolo dental, exodontia.

\section{REFERENCES}

1. Morton JJP, Malone MH. Evaluation of vulnerary activity by an open wound procedure. Arch Int Pharmacodyn 1972;196:117126.

2. Abdalla AE, Simões MJ, Mora AO, Focchi GRA, Kulay Jr L. Action of diclofenac sodium on the reparation process of the surgically-perforated myometrium of pregnant albino rats. Morphological and morphometrical evaluation. Gen Pharmac 1994;25:989-993.

3. Obeid G, Zhang X, Wang X. Effect of ibuprofen on the healing and remodeling in the rabbit temporomandibular joint. J Oral Maxillofac Surg 1992;50:843-849.

4. Lindholm TS, Tornkvist H. Inhibitory effect on bone formation and calcification exerted by the anti-inflammatory drug ibuprofen. An experimental study on adult rat with fracture. Scan J Rheumatol 1981;10:38-42.

5. Engesaeter LB, Sudmann B, Sudmann E. Fracture healing in rats inhibited by locally administered indomethacin. Acta Orthop Scand 1992;63:330-333.

6. Altman RD, Latta LL, Keer R, Renfree K, Hornicek FJ, Banovac $\mathrm{K}$. Effect of nonsteroidal antiinflammatory drugs on fracture healing: a laboratory study in rats. J Orthop Trauma 1995;9:392
400.

7. Huusko PJ, Nieminen LHE, Nieminen LS. The effect of indomethacin on tooth extraction wound healing in rats. Experientia 1975;31:1056-1058.

8. Mizuno H, Liang RF, Kawabata A. Effects of oral administration of various anti-inflammatory drugs on bone growth and bone wound healing in mice. Meikai Daigaku Shigaku Zasshi 1990;19:234-250.

9. Ro J, Sudmann E, Marton PF. Effect of indomethacin on fracture healing in rats. Acta Orthop Scand 1976;47:588-599.

10. Sato $\mathrm{S}$, Kim $\mathrm{T}$, Arai $\mathrm{T}$, Maruyama $\mathrm{S}$, Tajima M, Utsumi N. Comparision between the effects of dexamethasone and indomethacin on bone wound healing. Jpn J Pharmacol 1986;42:7178.

11. Sanches MG, Okamoto T, Carvalho ACP. Efeitos da prednisolona no processo de reparo em feridas de extração dental: estudo histológico em ratos. Rev Fac Odont Araçatuba 1975;4:195-200.

12. Lamano Carvalho TL, Bombonato KF, Brentegani LG. Histometric analysis of rat alveolar wound healing. Braz Dent J 1997;8:9-12.

13. Devlin H. Early bone healing events following rat molar tooth extraction. Cell Tissues Organs 2000;167:33-37.

14. Bombonato Prado KF, Lamano Carvalho TL, Franci JAA, Brentegani LG. Prolonged immobilization-induced stress delays alveolar bone healing. A histometric study in rats. Histol Histopathol 2001;16:481-485.

15. Lin W, McCulloch CAG, Cho M. Differentiation of periodontal ligament fibroblasts into osteoblasts during socket healing after tooth extraction in rat. Anatomical Record 1994;240:492-506.

16. Okamoto T, Okamoto R, Alves Rezende MCR, Gabrielli MFR Interference of the blood clot on granulation tissue formation after tooth extraction. Histomorphological study in rats. Braz Dent J 1994;5:85-92.

17. Dvivedi S, Tiwari SM, Sharma A. Effect of ibuprofen and diclofenac sodium on experimental wound healing. Indian J Exp Biol 1997;35:1243-1245. 